\title{
THE LITERATURE OF RHEUMATISM
}

\author{
BY \\ L. T. MORTON, F.L.A. \\ Librarian, National Institute for Medical Research \\ AND
}

E. G. L. BYWATERS, F.R.C.P.

Director, M.R.C. Rheumatism Unit, Canadian Red Cross Memorial Hospital, Taplow, and Professor of Rheumatology, Royal Post-graduate Medical School, London

In 1961 Dr. R. M. Stecher published a useful "World list of periodical literature in arthritis and rheumatism" (Arthr. and Rheum., 1961, 4, 378-88). After listing all known journals on the subject, he discussed their development and commented upon their importance.

The present list supplements Dr. Stecher's paper, bringing up to date the information concerning the items he recorded and adding the titles of journals that began publication after his list was published. Some reviews of the literature on rheumatism, the chief abstracting journals, and a few important textbooks are also recorded, together with the dates of recent international congresses.

\section{PERIODICALS}

A.I.R. Archives of Inter-American Rheumatology. Rio de Janeiro.

Vol. 1-8: 1958-65

Acta Physiotherapica et Rheumatologica Belgica, Brussels.

Vol. 1-10: 1946-55

Continuation of Annales de Médecine Physique et de Rhumatologie, 1938-1945

Continued as Journal Belge de Médecine Physique et de Rhumatologie

Acta Reumatologica Latinoamericana. Buenos Aires.

Vol. 1- : 1958- .

\section{Quarterly}

Acta Rheumatica. Moscow.

Vol. 1-2: 1929-30

Continued as Voprosy Revmatisma (Acta Rheumatica).

Acta Rheumatologica. Amsterdam.

Vol. 1-11, No. 43: 1929-39.

Acta Rheumatologica et Balneologica Pistaniana. Piestany. 1966- .

Vol. 1- : 1966-

Yearly.

Acta Rheumatologica Brasileira.

Vol. 1- : 1952-.

Acta Rheumatologica Scandinavica. Stockholm.

Vol. 1- : 1955- .

Quarterly. Papers in English, French, or German. Supplements published irregularly.

Annales de Médecine Physique et de Physiobiologie et de Rhumatisme. Antwerp.

$1938-45$.

Continued as Acta Physiotherapica et Rheumatologica Belgica.

Annals of the Rheumatic Diseases. London.

Vol. 1- : 1939-

Continuation of The Rheumatic Diseases, 1939, q.v.

6 issues a year. Summaries in French and Spanish. Includes abstracts of the world medical literature.

Supplements published irregularly. 
Archives of Medical Hydrology. London.

Vol. 1-17: 1922-39.

Archivos Argentinos de Reumatología. Buenos Aires.

Vol. 13- : 1950-.

Three issues a year. Continuation of Boletín de la Liga Argentina contra el Reumatismo, 1938-49. Organ of the Sociedad Argentina de Reumatología.

Arthritis and Rheumatism. New York.

Vol. 1- : 1958-.

6 issues a year. Official journal of the American Rheumatism Association.

Beiträge zür Rheumatologie. Berlin.

Vol. 1- : 1958-

One or more volumes a year.

Boletín de la Liga Argentina contra el Reumatismo. Buenos Aires.

Vol. 1-12: 1938-49.

Continued as Archivos Argentinos de Reumatologia.

Boletín de la Sociedad Argentina de Estudios Reumatológicos. No. 1-15: 1953-4.

Boletin de la Sociedad Chilena de Reumatologia. Santiago de Chile. 3 issues a year. Apparently commenced 1963; vol. 6 appeared in 1968.

Boletín Mexicano de Reumatología. Mexico.

Vol. 1- : 1961- .

Three issues a year. Organo oficiel de Sociedad Mexicana de Reumatologia.

Bollettino del Centro di Reumatologia OO.RR. Rome.

Vol. 1- : 1964- .

Quarterly.

British Journal of Rheumatism. London.

Vol. 1-2: 1938-40.

Bulletin of the Hospital for Joint Diseases. New York.

Vol. 1- : 1940-.

Twice a year.

Bulletin on the Rheumatic Diseases. New York.

Vol. 1- : 1950- .

Nine issues a year. Published by the Arthritis and Rheumatism Foundation.

Deutsche Gesellschaft für Rheumatologie. Veröffentlichungen. Berlin.

No. 1-6: 1927-31.

Egyptian Rheumatologist.

Vol. 1- : 1964-

Irregular. Proceedings of the Egyptian Society of Rheumatology.

Fysiatrický a Reumatologický Vestnik. Prague.

Vol. 44- : 1966-.

6 issues a year. Formerly Fysiatrický Vestnik.

Summaries in English, Russian, and Czech.

Fysiatrický Vestnik. Prague.

Vol. 1-43: 1923-65.

Journal Belge de Médecine Physique et de Rhumatologie. Brussels.

Vol. 11-18: 1956-63.

Continuation of Acta Physiotherapica et Rheumatologica Belgica, 1946-55.

Continued as Journal Belge de Rhumatologie et de Médecine Physique

Journal Belge de Rhumatologie et de Médecine Physique. Brussels.

Vol. 19- : 1964-

6 issues a year. Continuation of Journal Belge de Médecine Physique et de Rhumatologie, 1956-63.

Text in French, Dutch, or English. Organ of the Société Belge de Médecine Physique.

Postepy Reumatologii. Warsaw.

Vol. 1-2: 1954-56.

Continued as Reumatologia Polska. 
Probleme de Reumatologie. Bucharest.

Vol. 1- : 1953-

Reports on Chronic Rheumatic Diseases. London.

No. 1-4: 1935-38.

Published by the Committee on Chronic Rheumatic Diseases of the Royal College of Physicians of London.

Title changed to The Rheumatic Diseases, but after one issue (1939) continued as Annals of the Rheumatic Diseases.

Reports on Rheumatic Diseases. London.

No. 1- : 1959-

Published occasionally (about four a year) by the Arthritis and Rheumatism Council and circulated free of charge to the medical profession in Great Britain and Northern Ireland.

No. 35 was published in February, 1969.

Reumatism. Vilnius.

Vol. 1- : 1959- .

Reumatismo. Milan.

Vol. 1- : 1949-.

6 issues a year. Publishes an annual "Biblioteca", 1- : 1954- .

Organ of the Societā Italiana per lo Studio del Reumatismo.

Reumatizam. Zagreb.

Vol. 1- : 1954- .

6 issues a year. Organ of the Yugoslav Rheumatological Association.

Reumatologia Polska. Warsaw.

Vol. 1- : 1959- .

Quarterly.

Continuation of Postepy Reumatologii, 1954-56.

Title shortened to Reumatologia in 1963. Summaries in English, French, and Russian.

Revista Argentina de Reumatología. Buenos Aires.

Vol. 1- : 1936- .

Monthly.

Revista Brasileira de Reumatologia. Rio de Janeiro.

Vol. 1- : 1957-.

Quarterly.

Organ of the Sociedade Brasileira de Reumatologia.

Revista Española de Reumatismo y Enfermedades Osteoarticulares. Barcelona.

Vol. 1- : 1945- .

Quarterly.

Organ of the Sociedad Española de Reumatismo.

Revue du Rhumatisme et des Maladies Osteo-articulaires. Paris.

Vol. 1- : 1934-.

Ten issues a year.

Summaries in English, Spanish, and German. Includes abstracts of the world medical literature.

Published by the Ligue Française contre le Rhumatisme and the Société Française d'Orthopédie et de Traumatologie.

Rheumaprobleme. Leipzig.

Vol. 1-3: 1928-34.

Rheumatism. London.

Vol. 1-23, No. 1: 1938-67.

Rheumatism. New Delhi.

Vol. 1- : 1965- .

Quarterly.

Rheumatologia, Balneologia, Allergologia. Budapest.

Vol. 1- : 1961-

Quarterly.

Rheumatology: an annual review. Basel, Karger. 1967- .

Rhumatologie. Aix-les-Bains.

Vol. 1- : 1949-.

6 issues a year.

Published by the Centre de Recherche des Maladies Rhumatismales d'Aix-les-Bains. 
Ryumachi [Rheumatism]. Tokyo.

Vol. 1- : 1958- .

Official journal of the Japan Rheumatism Association. English summaries.

Voprosy Revmatizma. Moscow.

Vol. 1- : 1961-

Quarterly.

Voprosy Revmatizma (Acta Rheumatica). Moscow.

Vol. 3-12: 1932-40.

Continuation of Acta Rheumatica, 1929-30.

Zeitschrift für Rheumaforschung. Darmstadt.

Vol. 1- : 1938-

6 issues a year.

Official organ of the Deutsche Gesellschaft für Rheumatologie and other societies. Section of abstracts.

\section{INDEXING AND ABSTRACTING JOURNALS}

Arthritis and Rheumatic Diseases Abstracts. Bethesda, Md.

Vol. 1- : 1964-

Monthly. Annual index. Circulated free to interested physicians.

Excerpta Medica. Section 6B. Arthritis and Rheumatism. Amsterdam.

Vol. 1- : 1965- .

Monthly. These abstracts were, until 1969, the same as those published in Arthritis and Rheumatic Diseases Abstracts.

Index of Rheumatology. New York.

Vol. 1- : 1965- .

Monthly. Published by the American Rheumatism Association.

\section{REVIEWS}

The review of American and English literature on rheumatism and arthritis started in the Annals of Internal Medicine in 1935 has been maintained year by year since 1935 (1st Review) up to 1964 (16th Review) in the same journal. The first eight of these reviews (1935-1941) were reprinted in book form under the auspices of ISRA and published by Excerpta Medica, Amsterdam, 1961.

A European counterpart to this was first published by the European League against Rheumatism in 1957 under the editorship of L. J. Michotte, entitled Rhumatologie Européenne, Revue Critique de la Littérature.

The 17th and 18th Reviews, covering the years 1963-64 and 1965-66 respectively, have been published as supplements to Arthritis and Rheumatism (1966 and 1968).

\section{MONOGRAPHIC SERIES}

Documenta Rheumatologica Geigy. Basel (Acta Rheumatologica in English).

No. 1-17: 1953-50 (listed by Stecher in detail).

1959: "Prevention and treatment of polyarthritis by continuous and active immobilization of joints", by M. Kelly.

No. 18: "Über vertebrale, radikuläre und pseudoradikuläre Syndrome", Teil I, by A. Brügger (1960).
1961: Special issue on Rheumatoid Arthritis. (Symposium of Italian studies).

No. 19: "Über vertebrale, radikuläre und pseudora dikuläre Syndrome", Teil II, by Acọ Brügger and D. Gross (1962).

No. 20: "Der akute Gelenkrheumatismus des Erwachsenen", by G. Ablard and A. Larcan (1963).

No. 21: "Die Epiphyseolysis capitis femoris", by W. Taillard, A. Mégevand, P. ScholderHegi, and E. Morscher (1964).

No. 22: "Kurze Geschichte der ankylosierenden Spondylitis und Spondylose", by $\mathrm{H}$. Buess and H. M. Koelbing (1964).

No. 23: "Physiotherapie bei degenerativ-rheumatischen Erkrankungen der Wirbelsäule", by G. Kaganas (1967).

Superseded by Folia Rheumatologica and Acta Clinica, 1967-

Monographies Internationales de Rhumatologie, Paris.

Publiées par F. Delbarre et A. Peylan.

L'Expansion Scientifique Francaise.

No. 1, 1965: Morceaux choisis sur les generalités et principales formes des rhumatismes inflammatoires cryptogénétiques.

No. 2, 1967: Morceaux choisis sur les rhumatismes inflammatoires chroniques à l'enfant.

Rheumatismus in Forschung und Praxis. Ed. W. Belart.

No. 1- : Bern, 1962-

Published under the auspices of the Schweizerische Rheumaliga, Zurich. 


\section{CONFERENCES AND CONGRESSES}

Arthritis and Rheumatism Foundation Conference SERIES

No. 1. 1954: National Conference on "Research and Education in the Rheumatic Diseases".

No. 2. 1957: 2nd National Conference on "Research and Education in the Rheumatic Diseases".

No. 3. 1958: International Conference on "Population Studies in Rheumatoid Arthritis".

No. 4. 1959: Conference on "Comparative Pathology of Arthritis and Rheumatism".

No. 5. 1961 : Conference on "Some Recent Advances in the Physiology and Biochemistry of Adrenal Steroids".

No. 6. 1962: Conference on "Host Response Mechanism in Rheumatoid Arthritis".

No. 7. 1962: Conference on "Biology of Connective Tissue Cells".

Since 1962, such conferences, sponsored largely by the Arthritis and Rheumatism Foundation, have been published as supplements to Arthritis and Rheumatism.

The Second Conference on Population Studies in the Rheumatic Diseases, held in Rome, 1961, was published as "The Epidemiology of Chronic Rheumatism", 2 vols., Oxford, Blackwell, 1963.

The Proceedings of the Third International Symposium on "Population Studies of the Rheumatic diseases" was published in 1968 by Excerpta Medica.

Proceedings of ISRA Conferences

(1) 1959: "Social Aspects of Chronic Rheumatic and Joint Affections".

(2) 1963: "Radiological Aspects of Rheumatoid Arthritis", published in the same series, No. 61, 1964.

(3) 1969: "Early Synovectomy in Rheumatoid Arthritis".

INTERNATIONAL CONGRESSES

VII 1949, New York.

VIII 1953, Geneva.

IX 1957, Toronto (pre-Congress abstracts).

X 1961, Rome (3 volumes of Proceedings published in Rome, 1961).

XI 1965, Mar del Plata (pre-Congress abstracts).

XII 1969, Prague (pre-Congress abstracts).

European Congresses

I 1947, Copenhagen.

II 1951, Barcelona.

III 1955, Scheveningen (pre-Congress abstracts).

IV 1959, Istanbul.

V 1963, Sotckholm (pre-Congress abstracts).

VI 1967, Lisbon (pre-Congress abstracts, and Proceedings, 1969).

South-East Asia and Pacific League against

RHEUMATISM

1st Congress, 1968, Bombay (pre-Congress abstracts).
Panamerican Congresses

I 1955, Brazil.

II 1959, U.S.A.

III 1963, Chile.

IV 1966, Mexico.

V 1970, Uruguay.

\section{BOOKS}

Copeman, W. S. C. (ed.)

"Textbook of the Rheumatic Diseases." 4th ed.

Edinburgh, Livingstone, 1969.

(1st ed., 1948; 2nd, 1955; 3rd, 1964).

Copeman, W. S. C.

"A Short History of the Gout and the Rheumatic Diseases." Cambridge University Press, 1964.

Hill, A. G. S. (ed.)

"Modern Trends in Rheumatology." Vol. 1. London, Butterworth, 1966.

Hollander, J. L., et al. (ed.)

"Arthritis and Allied Conditions: a Textbook of Rheumatology." 7th ed. Philadelphia, Lea and Febiger, 1966.

(The first three editions (1940-44) were by B. I. Comroe; the fourth edition, by J. L. Hollander, appeared in 1944; 5th, 1953; 6th, 1960).

Ruhl, M. J., and Sokoloff, L.

"A Thesaurus of Rheumatology." New York, Grune and Stratton, 1965.

Over 11,000 terms. Reprinted from Arthritis and Rheumatism.

Talbott, J. H.

"Gout." 3rd ed. New York, Grune and Stratton. 1967.

(1st ed., 1953; 2nd, 1957).

HANDBOOK OF THE INTERNATIONAL League against RHEUMATISM

This is a list of the members, with their addresses, of each constituent national league, and includes also a brief summary of the facilities and organization of rheumatological services in the individual countries. The first Handbook was published in 1950 , the second in 1955 , the third in 1961 , and the fourth in 1967.

This listing would be incomplete if it did not refer to the historical collection of books, reports, periodicals and manuscripts which form the library of the Heberden Society of Great Britain and Northern Ireland. This library is housed at the Royal College of Physicians of London, under the care of Dr. W. S. C. Copeman, honorary librarian of the Heberden Society, and Mr. L. M. Payne, librarian of the College. 